\title{
A Study on Amazon Prime Air for Feasibility and Profitability-- A Graphical Data Analysis.
}

\author{
Dr. Vinay Pandit, Dr. Arun Poojari
}

\begin{abstract}
Amazon Prime Air, A Futuristic Delivery System For Company's Products. ${ }^{[1]}$ The Company Has Been Developing Multicolor Miniature Unmanned Air Vehicle (Miniature UAV) Technology Intended To Utilize GPS To Autonomously Fly Individual Packages To Customers' Doorsteps Within 30 Minutes Of Ordering. ${ }^{[1]}$ To Qualify For 30 Minute Delivery, The Order Must Be Less Than Five Pounds, Which, According To Bezos, Includes $86 \%$ Of The Packages Amazon Currently Sells. ${ }^{[1]}$ The Order Must Also Be Small Enough To Fit In The Cargo Box That The Craft Will Carry, And The Delivery Location Must Be Within A Ten Mile Radius Of A Participating Amazon Order Fulfillment Center. ${ }^{[1]}$

The Research Undertaken Highlights The Feasibility As Well As The Profitability Aspect For The Company .For This Purpose An Attempt Was Made By The Researcher To Study the Feasible And Profitable Aspect Of Proposed Business Venture Using Exploratory And Descriptive Research.

The Researcher Identified That Presently, The Biggest Hurdle Facing Amazon Prime Air Is That Commercial Use Of UAV Technology Which Is Not Yet Legal In The United States In The FAA Modernization And Reform Act Of 2012. And Also Research Concludes The Concerns Of Public Regarding This Technology Include Public Safety, Privacy, And Package Security Issues. Thus It Is Concluded That The Proposed Business Idea May Not Be Viable In Current Business Environment.
\end{abstract}

\section{Introduction}

Amazon Prime Air,' A Futuristic Delivery System For Company's Products. ${ }^{[1]}$ The Company Has Been Developing Multicolor Miniature Unmanned Air Vehicle (Miniature UAV) Technology Intended To Utilize GPS To Autonomously Fly Individual Packages To Customers' Doorsteps Within 30 Minutes Of Ordering. ${ }^{[1]}$ To Qualify For 30 Minute Delivery, The Order Must Be Less Than Five Pounds, Which, According To Bezos, Includes $86 \%$ Of The Packages Amazon Currently Sells. ${ }^{[1]}$ The Order Must Also Be Small Enough To Fit In The Cargo Box That The Craft Will Carry, And The Delivery Location Must Be Within A Ten Mile Radius Of A Participating Amazon Order Fulfillment Center. ${ }^{[1]}$

Assuming Amazon Prime Air Eventually Launches, Though, Here Are A Handful Of Predictions About The System Itself And Delivery-By-Drone Systems In General.

Amazon Won't Be The First To Launch A Consumer Delivery-By-Drone Program At This Scale. You May Recall The Domino's Pizza "Domicopter" Concept That Made The Rounds Earlier This Year. Pizza By Drone? Now We are Talking. And Apparently China Is Well Ahead Of The U.S. In The Delivery-By-Drone Department, With A Company Called SF Express Reportedly Testing A System "Built For Delivering Packages To Remote Areas," Reports Quartz.

Here In The U.S., Expect Something Like This Domino's Experiment To Take Off (Pun Intended) First. The Stakes Are Much Lower: We're Talking About Mediocre Pizza That In The Event Of A Drone Failure Or Miss-Delivery Can Be Redelivered By An Actual Driver Relatively Quickly. Domino's Has Enough Brick-And-Mortar Locations To Provide A Meaningful Fail safe, In Other Words.

What Happens If This Amazon Drone Botches Your Delivery? Will The Company Then Send Out A Driver From Its Distribution Center To Hand-Deliver The Stick Of Deodorant You Ordered Or Will The Company Simply Apologize And Ship It Out Normally?

UPS, FedEx And The USPS Will Complain About Unfair Competition.

Well, The USPS Will Definitely Complain. If UPS And FedEx Are Smart, They'll Just Build Their Own Drones For Delivering Small Packages. This Type Of System Could Conceivably Work Well For The Usps, Of Course, Given That Your Daily Mail Delivery Generally Weighs Less Than Five Pounds, But I Can't Imagine The Post Office Pulling Something Like This Together In A Timely Fashion. Especially A System That Can Reliably Deliver Postal Mail To A Secure Location Like A Mailbox Day After Day. As For UPS And FedEx, You Have To Believe Both These Companies Are Either Already Working On Delivery-By-Drone Systems Or They're Seriously Researching Them.

One Bad Delivery Will Make For Big Headlines And An Even Bigger Nightmare.

Amazon May Not Have To Deal With This Too Much If The First Point I Make Up Above Comes True. People May Be Comfortable With Delivery Drones By The Time Amazon Prime Air Launches. But There Will Undoubtedly Be A Certain Subset Of People At Some Point In Time Who Get Bent Out Of Shape About 
The Idea Of Drones Flying Around And Delivering Packages. Though Amazon's System Sounds Pretty Much Automated, It's Not Far-Fetched To Think That Some Drone Delivery Systems From Other Companies Might Have An Actual Human On The Other End Guiding Things. And You'd Have To Believe That Amazon Would Build In Some Sort Of Override Function Where A Human Could Grab Control Of Drones.

\section{Research Problem}

\section{Methodology Of The Study}

An Attempt Was Made By The Researcher To Identify Whether "Amazon Prime Air" Will Be A Feasible And Profitable Endeavor For Amazon. Thus The Research Problem Identified Was Viability And Feasibility Of The Business Idea Of Amazon.

\section{Objectives Of The Study}

1. To Study The Viability Of “Amazon Prime Air” Business Model.

\section{Sources Of Data}

\section{Primary Data}

Primary Data Are Those Which Are Collected For The First Time And Which Is Original In Character. There Are Several Methods Of Data Collection, Particularly In Descriptive Researches. This Includes Following Methods. Observation Method, Interview Method, Collection Of Data Through Questionnaires, Such As Warranty Cards, Content Analysis, Projective Techniques, Depth Interviews And Systems Audits Etc.

A Structured Questionnaire Was Built In Correlation With Objective Of Research. Thus Data Using Structured Questionnaire Was Collected From Shoppers.

\section{Secondary Data}

Secondary Data Represents A Very Powerful Tool For The Researcher As Entire Research Work Is Carried Out On The Basis Of Secondary Data. It Is Nothing But The Backbone Of Research Work. Secondary Data Is The One Which Has Already Been Collected And Analyzed By Someone Else. Usually This Analyzed Data Is Available In The Published Form.

The Articles Which Were Based On The Related Topic Were Taken From Newspapers \& Magazines Which Were Published. Literature From The Websites Was Also Reviewed

\section{Sampling Design}

A Sampling Design Is A Definite Plan For Obtaining A Sample From A Given Population. It Refers To The Technique Or The Procedure The Researches Would Adopt To Select Units For The Sample. It Will Also Indicate The Number Of Units To Be Included In The Sample Also Known As Sample Size. Sampling Design Is Determined Before Data Are Collected.

The Total Sample Size Decided By Researcher Was 50 Across New York City. All Clusters Namely, Students, Service Class, Business Class, Professional And Others Was Be Considered For The Same. Researcher Had Made An Attempt That The Sample Size Was Adequate, Representative And Estimator With Sufficiently High Precision.

\section{Research Area}

Data was collected from New York City in America which Encompasses Central And Western Part Of New York. This Scope Of Study Was Taken Due To Logistical Problem. All Attempts Were Made To Collect The Data From Different Parts Of New York City. Also One More Reason Why This Area Was Taken Under Consideration Was That The Area Under Research Was Heterogeneous In The Sense, All Class Of People Could Be Easily Contacted.

\section{Limitation Of The Study}

1. There Was No Control Over Respondent Biasness Thus, Even Though The Researcher Has Made An Attempt To Collect Authentic Information From The Respondent, It Is Observed That Respondent S Biasness May Play A Significant Role.

2. The Researcher Has Made An Attempt To Include Good Quantum Of Secondary Information With Sources Of References, However The Researcher Has Believed The Secondary Information Is Authentic

3. The Researcher Claims That A Limited Time Period And Limited Budget Were Indeed The Limitation Of The Research.

4. However The Study Was Restricted To New York, Only Selected Place Of New York Was Considered For The Research, Thus Neglecting The Views Of The Respondent In Other Places 
5. The Researcher Has Defined Only 5 Demographic Factors Which Were Considered For Collecting Responses

6. A Limited Sample Of 50 Respondent Were Considered For This Study

\section{SWOT Analysis}

A Tool That Identifies The Strengths, Weaknesses, Opportunities And Threats Of An Organization. Specifically, SWOT Is A Basic, Straightforward Model That Assesses What An Organization Can And Cannot Do As Well As Its Potential Opportunities And Threats. The Method Of SWOT Analysis Is To Take The Information From An Environmental Analysis And Separate It Into Internal (Strengths And Weaknesses) And External Issues (Opportunities And Threats). Once This Is Completed, SWOT Analysis Determines What May Assist The Firm In Accomplishing Its Objectives, And What Obstacles Must Be Overcome Or Minimized To Achieve Desired Results.

\begin{tabular}{|ll|ll|}
\hline Strength & & \multicolumn{2}{|l|}{ Weakness } \\
1. & On Time Delivery & 1. & Unclear ROI \\
2. & Meeting QCD Expectations & 2. & Weather Theft \\
3. & Limited Competition & 3. & Vandalism \\
4. & Highly Time Effective & 4. & Problem Of Range \\
5. & High Barrier To Entry & 5. & Landing In Every Location \\
\hline Opportunity & Threat & \\
1. & Continued Expansion Of Business & 1. & Changes In The Regulations System \\
2. & Ability To Develop Additional Customer & 2. & Threat Of New Entrant \\
3. & Untapped Market & 3. & Threat Of New Substitute \\
4. & Affiliate Relation With Related Vendors & 4. & Lack Of Retrofitters \\
\hline
\end{tabular}

1. Age

VI. Data Analysis

\begin{tabular}{|l|l|l|l|l|}
\hline Age & $16-21$ & $22-30$ & $31-40$ & $\begin{array}{l}40 \text { And } \\
\text { Above }\end{array}$ \\
\hline Respondent/Sample & 12 & 17 & 10 & 11 \\
\hline
\end{tabular}

\section{Gender}

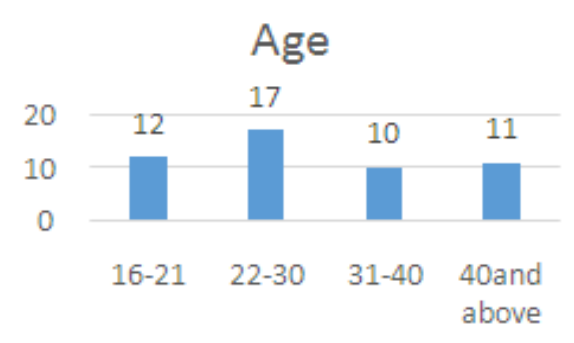

\begin{tabular}{|l|l|}
\hline Male & 28 \\
\hline Female & 22 \\
\hline
\end{tabular}

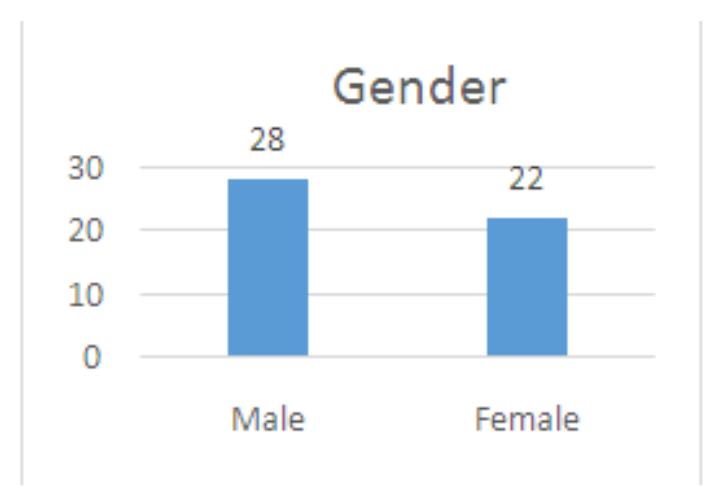

3. Qualification 
A Study On Amazon Prime Air For Feasibility And Profitability-- A Graphical Data Analysis....

\begin{tabular}{|l|l|l|l|l|}
\hline Qualification & High School & UG & Graduate & Post Graduate \\
\hline & 08 & 22 & 11 & 09 \\
\hline
\end{tabular}

4. Marital Status

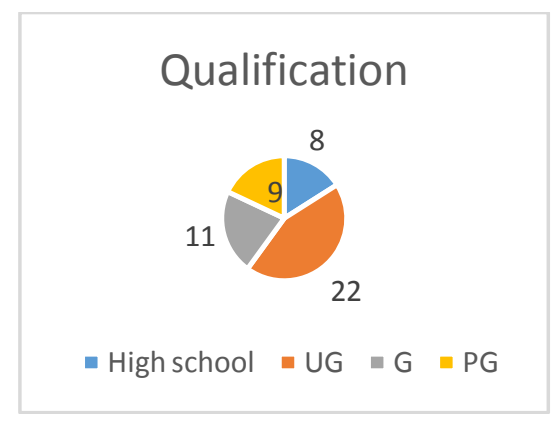

\begin{tabular}{|l|l|}
\hline Married & 19 \\
\hline Unmarried & 31 \\
\hline
\end{tabular}

\section{Marital Status}

\section{- Married - Unmarried}

5. Income Level (In 1000 \$ Per Year)

\begin{tabular}{|l|l|l|l|}
\hline Below 50\$ & $50 \$-70$ & $70 \$-1$ Lac & 1 lac-1.5lac \\
\hline 08 & 22 & 11 & 09 \\
\hline
\end{tabular}

6. Occupation

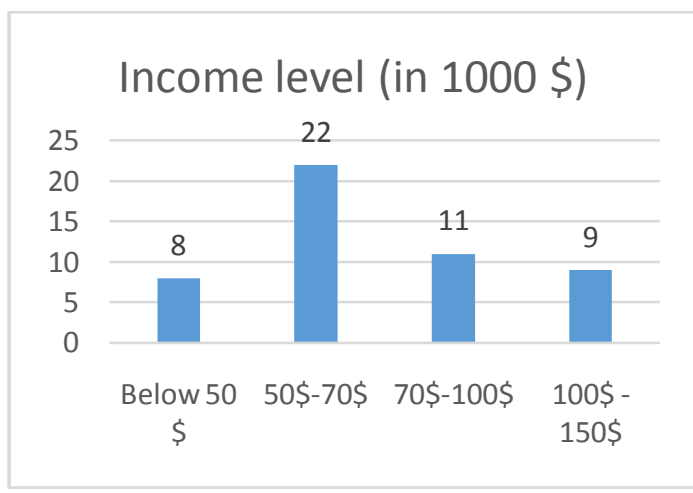

\begin{tabular}{|l|l|l|}
\hline Students & Business & Service \\
\hline 11 & 15 & 24 \\
\hline
\end{tabular}




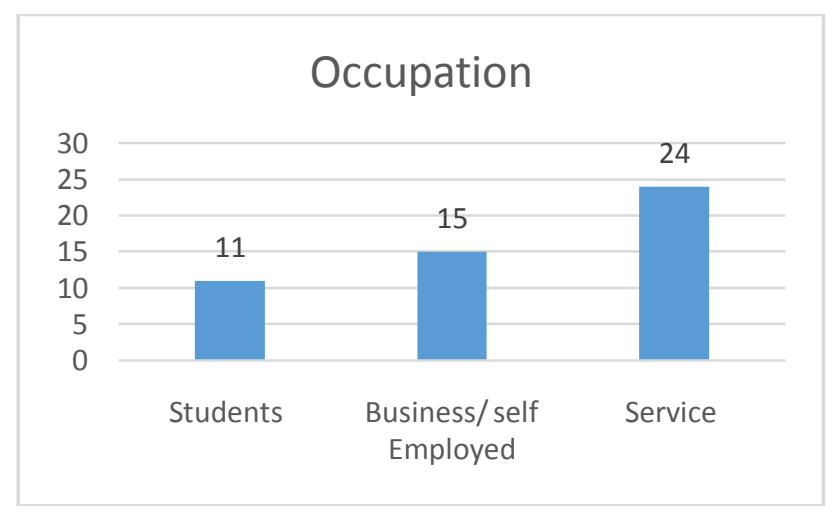

7. Do You Agree That The Services Offered By Amazon Prime Air Is Cost Effective?

Cost effectiveness

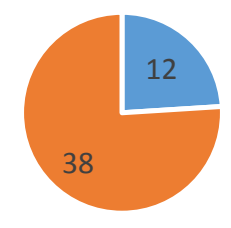

- YES - No

The Survey Was Done On 50 People Out Of Which 38 Respondent Have Said It In Not Cost Effective And 12 Of Them Said It Is Cost Effective.

8. Do You Think That The Services Offered By Amazon Prime Air Is Not Viable Due To The Risk Of Theft?

Risk factor

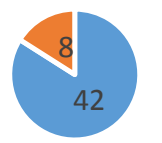

- Yes $=$ No

The Survey Was Done On 50 People Out Of Which 42respondent Have Said It Is Not Viable Due To The Risk Of Theft And 8 Respondent Have Said There Is No Risk Of Theft Involved.

9 Do You Think The Technology Used For Transportation By Amazon Prime Air Will Have Legal Hurdles?

Legal hurdles

7

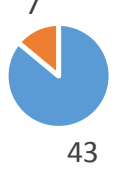

- yes $\square$ No 
The Survey Was Done On 50 People Out Of Which 43respondent Have Said It Will Have Legal Hurdles And 7 Respondent Have Said There Will Not Be Any Legal Hurdles.

10 Do You Think That Technology Used Will Be Able To Meet High Demand In Future?
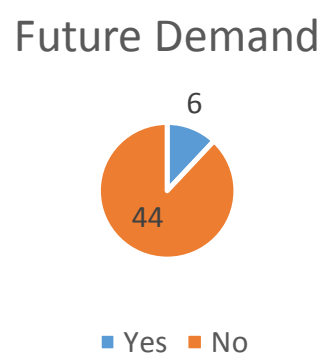

The Survey Was Done On 50 People Out Of Which 44respondent Have Said It Will Not Meet Future Growing Demand And 6 Respondent Have Said They Will Not Be Able To Meet Future Growing Demand.

\section{Conclusion}

The Researcher Identified That Presently, The Biggest Hurdle Facing Amazon Prime Air Is That Commercial Use Of UAV Technology Which Is Not Yet Legal In The United States In The FAA Modernization And Reform Act Of 2012. And Also Research Concludes The Concerns Of Public Regarding This Technology Include Public Safety, Privacy, And Package Security Issues And Theft. Thus It Is Concluded That The Proposed Business Idea May Not Be Viable In Current Business Environment Looking Into The Prospective Of The Future Demand.

\footnotetext{
[1]. 13 Remote-Control Aerial Tours Of Abandoned Places

[2]. TIME Magazine Cover Story: Rise Of The Drones

[3]. FAA Reveals List Of Colleges And Police Departments That Can Fly Drones

[4]. Occupy The Internet: Protests Give Rise To DIY Data Networks

[5]. Navy Looking To Use Helicopter Drones To Hunt Pirates
} 